\title{
Spatial distribution and the facility evaluation of the service and rest areas in the toll motorway network of the European Union
}

\author{
Heriberto Pérez-Acebo ${ }^{1}$ (D) Ander Romo-Martín ${ }^{2}$ (D) Daniel J. Findley ${ }^{3}$ (D)
}

Received: 25 November 2020 / Accepted: 21 July 2021 / Published online: 17 August 2021

(c) The Author(s) 2021

\begin{abstract}
Among safety countermeasures for roads, service and rest areas play a vital role, providing a place to stop or rest during a journey and offering services such as petrol stations. Due to their importance, they must be logically distributed along routes at convenient locations with respect to travel itineraries and must be conveniently equipped. These needs become even more apparent on motorways that charge a toll to use the road, because drivers tend avoid leaving the motorway until they have reached their planned destination or departure point. The objective of this paper is to explore the spatial distribution of the service and rest areas on the toll motorways (or freeways) in the European Union (EU) and their facilities. Additionally, the distance and facility specifications established by the regulations of each country were compared. The EU was selected for this evaluation because of the virtual inexistency of borders and the substantial international traffic volumes that result from this relatively free flow of traffic between countries. Countries with a toll road network over $100 \mathrm{~km}$ were included: Italy, Portugal, France, Spain, Poland, Greece, and the Slovak Republic. Analysis of average and maximum distances between areas and the facilities provided showed a great variability due to different distribution policies. Few regulations exist that establish maximum distances between areas. Standardization of the spatial distribution of these facilities, on both free and tolled roadways, in the EU would benefit drivers, especially on long journeys, creating a consistent and predictable network of areas and services.
\end{abstract}

Keywords Rest area $\cdot$ Service area $\cdot$ Toll motorway $\cdot$ Paying freeway $\cdot$ Road safety

Heriberto Pérez-Acebo

heriberto.perez@ehu.eus

Extended author information available on the last page of the article 


\section{Introduction}

For decades, road transport has been the most important transport mode in Europe, with over $75 \%$ of the transport modal distribution, for both passengers and freight, with a similar trend throughout the European Union (EU) (EUROSTAT, 2019). The traffic distribution of road transport is not equally distributed between roadway functional classifications and, generally, the most important network level, consisting of freeways or motorways (used as synonyms in this paper), serves the majority of the road traffic, with approximately $50 \%$ of traffic volumes, while representing only a small portion of the distance of the network. Once again, this trend is repeated internationally with slight variations (Findley et al., 2015; Kraemer et al., 2009). Furthermore, the EU promotes a Single European Transport Area (SETA) to facilitate the movements of citizens and freight, reducing costs and enhancing the sustainability of European transport (Commission of the European Communities, 2001). Consequently, the EU developed the Trans-European Transport Network (TEN-T), a planned network of roads, railways, airports, and water infrastructure. TENT-T aimed to coordinate improvement of primary roads, railways, inland waterways, airports, seaports, inland ports, and traffic management systems, providing integrated and intermodal long-distance, high-speed routes (European Parliament and Council 1996). The guidelines for the development of the TEN-T were successively modified to account for new policies and new countries in the EU, which impacted traffic flows (European Parliament and Council 2004) and includes the Eastern Partnership member states. Highways included in the corridors of the TEN-T consist mainly of motorways and expressways (European Communities, 2005).

The aim of any highway administration is to provide a safe and comfortable road infrastructure to users, preserving the network in serviceable condition (Eksler, 2008; Pérez-Acebo et al., 2020, 2021; Santos et al., 2019). Among those safety elements that must be taken into consideration to provide safer conditions to road networks are the service and rest areas.

Service areas are usually defined as places near the highway, specifically designed and constructed to host facilities for motorists, such as, petrol stations, shops, cafés and/or restaurants, hotels, garages, and similar services. Rest areas may be defined as areas adjacent to the road equipped with a place for parking any type of vehicle, and sometimes, facilities planned for users to have rest during their travels (Banerjee et al., 2009; Gates et al., 2013). Due to the importance of a petrol station in road transport, its presence has traditionally been employed to distinguish these two areas (this paper uses this definition-an area with a petrol station is a service area and if an area does not have a petrol station, it is a rest area). If there is a petrol station at a service area, other services typically accompany it, such as shops, cafés, restaurants, and, sometimes, hotels and garages. Conversely, rest areas are designed to provide a place to relax, including facilities like toilets, picnic areas, and recreational spaces. Commercial facilities, such as cafés or restaurants, are seldom present at rest areas. Toilets are typically available at both types of areas. Therefore, service and rest areas are designed 
to provide a place to stop during a journey, relax, service the vehicle, if necessary. Due to the importance of service and rest areas on road safety, they must be conveniently and properly distributed relative to itineraries of travelers. Rest or service areas concentrated in a single part of an itinerary leads to substantial distances without facilities. Needs can arise at any point along a journey and therefore, a homogeneous distribution of these places is recommended. Moreover, these areas must be designed and equipped with the necessary services and facilities and maintained in good condition.

The adequate distribution of rest and service areas along important highways, such as those included in the TEN-T network and also any of the primary roads (motorways or freeways, and expressways), is even more necessary because these highways are generally used to travel long distances, and, hence, the need of making a stop is more probable. Furthermore, in the case of tolled motorways, their importance becomes even more evident. Motorways go through various cities, which can be reached for a service, if necessary, however, on tolled motorways, exiting the roadway to use a service and coming back to the same point, would imply an extra cost. Pérez-Acebo and Romo-Martín (2019) interviewed 124 drivers on a toll motorway in Spain to learn about their attitude with respect to leaving the motorway. Although more than three quarters of them $(77.4 \%)$ would exit the infrastructure for a minor vehicle repair, only 1 of 5 (20.8\%) would leave the motorway to go to a hotel if it is not previously planned. Conversely, visiting a petrol station was not a common reason for leaving the tolled motorway (less than 5\% of respondents). These results show that motorists will only leave a tolled motorway for a previously planned destination or if a problem arises with the vehicle. Therefore, motorists on a tolled motorway will continue their journey with access to the available service and rest areas on the toll motorway.

Few references can be found in the literature about the optimal distance between service and rest areas. Fatigue is the cause of approximately $25 \%$ of highway crashes and, hence, a break from driving is recommended every $2 \mathrm{~h}$ for drivers (regardless of the distance travelled) or after driving 150/200 km (González-Luque \& ÁlvarezGonzález, 2002). Banerjee et al. (2009) analyzed the crashes related to fatigue from a spatial perspective and concluded that there were fewer fatigue-related crashes in zones after rest areas, whereas the crashes related to other causes maintained their proportion in these zones. An influence area of $48.28 \mathrm{~km}$ (30 miles) was established as the area where fatigue-related crashes decrease (Taylor et al., 1999). Similarly from another study, a distance of $32.18 \mathrm{~km}$ (20 miles) around the rest areas was established as the area where beneficial effects of the rest area on fatigue-based crashes (McArthur et al., 2013). Kang et al. (2015) highlighted that fatigue-related effects are more prominent on rural roads. Additionally, Seya et al. (2020) showed that the presence of restaurants and shops and the quantity of parking places in these areas are an attractive factor for truck drivers. Moreover, Jung et al. (2017) showed a drowsy driving crash reduction of $14 \%$ if rest areas were introduced between main service areas. With regard to the cost of maintaining these areas in serviceable condition, Gates et al. (2013) indicated that toll motorways in Michigan obtained a benefit/cost of 3.36 for standard rest areas and a ratio of 4.00 for rest areas with tourist information, including as benefits in the methodology: travel diversion savings, 
comfort and convenience benefits, and crash reductions; and for tourist information, increased spending of tourists. The construction, rehabilitation, operation and, periodic maintenance activities were considered as costs in the research. Service and rest areas with tourist information have been shown to have a beneficial impact on the tourism economy (Gates et al., 2013).

Service and rest areas play a vital role as a safety element in a road network, and particularly, on tolled motorways, where motorists tend to remain. The objective of this paper is to study the spatial distribution of service and rest areas on tolled motorways in the European Union and the available facilities in each of the areas. The analysis included all the countries with toll motorways in the EU because there are no physical customs checkpoints between the EU countries and, generally, long distance movements for both passenger and freight traffic, use the primary highway corridors, like those typically included in the TEN-T network. The analysis was conducted for each country with toll motorways, and existing standards about the minimum or maximum distances between areas and facilities are summarized.

\section{Methodology}

The literature review demonstrated that drivers do not typically leave a toll motorway unless it is already included in their planned itinerary or if there is an operational problem with their vehicle (Pérez-Acebo \& Romo-Martín, 2019). Therefore, each of the tolled motorways is considered as a "tunnel" because drivers act as if there is no exit from it. Moreover, fencing surrounds this type of infrastructure, to avoid prohibited entering and exiting and to prevent animals from entering the motorway. Combined with strict access control that only allows vehicles at interchanges, the concept of considering a toll motorway as a tunnel is feasible, because of physical limitations of the roadway itself and the psychological aspects of driver behavior to remain on the roadway from the initial to the final point.

Due to the cross-border and international travel aspect of the primary highway system considered in this study, the entire length of the roadway is considered as a part of a longer journey. Each tolled motorway is considered in its entire length, from the first point where paying is compulsory to the first exit after the last toll barrier. When crossing the last toll barrier, generally, there is a distance to travel until the next exit. Similarly, from the last non-tolled entrance until the first central toll barrier, there is a distance where it is not possible to leave the motorway.

The following example illustrates this proposed terminology and methodology. A freeway of $250 \mathrm{~km}$ is considered and the initial tolling point is located at marker post 0 and the final tolling point is at marker post 250. Each service or rest area along the roadway is located at the specified marker post and the facilities provided at it, as shown in Table 1.

Using information in Table 1, the successive distances between service areas can be calculated: $80 \mathrm{~km}, 100 \mathrm{~km}$, and $70 \mathrm{~km}$. The entire length of the infrastructure is considered, so the average distance between service areas, $D_{a v \text {,serv.area }}$, can be obtained by Eq. (1): 


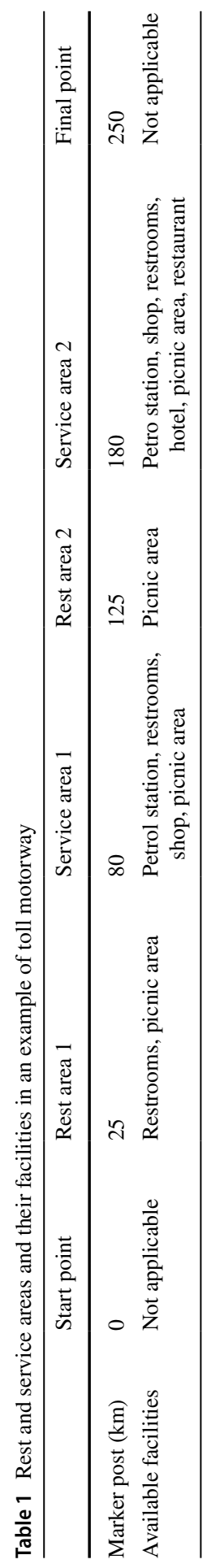




$$
D_{a v, \text { serv.area }}=(80+100+70) / 3=83,33 \mathrm{~km}
$$

As shown in Eq. (1), the average distance between any type of area or facility $i$, $D_{a v, i}$, can be calculated using the total length of the freeway, $L$, and the number of the studied area or facility $i$ that is present in the freeway in that direction, $N_{i}$, by means of Eq. (2):

$$
D_{a v, i}=L /\left(N_{i}+1\right)
$$

Using Eq. (2), the average distance for each type of area or facility can be calculated for the example motorway (Table 2).

In addition to the average distance between the same facilities or types of area, the maximum distance is another key factor because it represents the distance a driver could encounter without that service on a portion of the road. The maximum distance does not depend on the total number of that facility or area, which could provide an adequate average distance (Eq. 2). If this maximum distance is large, crashes related to fatigue or drowsiness are more probable to appear (Banerjee et al., 2009; McArthur et al., 2013). The use of some services like shops, restaurants, or hotels can be planned, but others, such as restrooms, cannot be scheduled in advance. The minimum distance between areas or services is interesting as it indicates the minimum distance between them to maintain the competence or guidelines set forth by the roadway authority. Table 2 shows the maximum and minimum distance for each type of area and facility in the example.

The analysis was conducted for each direction, because, not all areas or their facilities are duplicated in both directions nor located at the same point. The distances can also be observed from the point of view of the entire network of tolled motorways within the country by computing the average distance between facilities or areas in a country network, $D_{a v, i, c o u n t r y} . D_{a v, i, c o u n t r y}$ is calculated as the average value of the average distances between that facility or area $i$ in each of the $M$ directions of the motorways that compose the network of the country (Eq. 3).

Table 2 Average distances and minimum and maximum distances between services and areas in the example of Table $1(\mathrm{~km})$

\begin{tabular}{llll}
\hline Facilities or areas & $\begin{array}{l}\text { Average distance between } \\
\text { facilities or areas }(\mathrm{km})\end{array}$ & $\begin{array}{l}\text { Minimum distance } \\
\text { between facilities or areas } \\
(\mathrm{km})\end{array}$ & $\begin{array}{l}\text { Maximum distance } \\
\text { between facilities or } \\
\text { areas }(\mathrm{km})\end{array}$ \\
\hline Service area & 83.33 & 70 & 100 \\
Area(service or rest area) & 50 & 25 & 70 \\
Restrooms & 62.5 & 25 & 100 \\
Picnic area & 50 & 25 & 70 \\
Petrol station & 83.33 & 70 & 100 \\
Shop & 83.33 & 70 & 100 \\
Restaurant & 125 & 70 & 180 \\
Hotel & 125 & 70 & 180 \\
\hline
\end{tabular}




$$
D_{a v, i, \text { country }}=\sum_{j=1}^{M} D_{a v, i, j} / M
$$

where $D_{a v, i, j}$ is the average distance for a service or area $i$, in the direction $j$ of a motorway, and $M$ is the total number of directions on the tolled motorways of that country.

Another parameter is the ratio of a service or facility in the network, $R_{i}$, in $\mathrm{km} /$ facility or area, calculated by Eq. (4)

$$
R_{i}=\sum_{j=1}^{j=M} L_{j} / \sum_{j=1}^{j=M} n_{i}
$$

where $L_{j}$ is the distance of each of the $M$ directions of the tolled motorways in a country, and $n_{i}$ is the number of areas or facilities $i$, in each of the $M$ directions.

Although these two parameters, $D_{a v, i, c o u n t r y}$ and $R_{i}$ can be regarded as similar, the first one is dependent on the length of each freeway, as different values could be obtained with the same total length of the network and the same quantity of facilities. For example, in country A, if there are 10 service areas in each direction of the 2 highways of $1000 \mathrm{~km}$ and in country $\mathrm{B}$, there is 1 service area in each direction of the 20 highways of $100 \mathrm{~km}$ that exist in a network. In both cases, there are 40 services areas for a total network of $4000 \mathrm{~km}$, and hence, in both cases, $R_{i}=100 \mathrm{~km} /$ service area. However, the average value of the average distance between service areas $\left(D_{a v, \text { serv.are,country }}\right)$ is different. In country A the average distance is $90.9 \mathrm{~km}$ and in country B the average distance is $50 \mathrm{~km}$.

The average value of the maximum distances for each type of area or facility in the country, $D_{\text {max }, i, c o u n t r y}$, is the average of the maximum distances observed in each direction of the motorways, calculated, by Eq. (5)

$$
D_{\max , i, \text { country }}=\sum_{j=1}^{M} D_{\max , i, j} / M
$$

where $D_{\max , i, j}$ is the maximum distance between the same area or facility $i$, in a $j$ direction.

Additionally, for each facility, the minimum distance and the maximum distance between the facilities in the complete network were studied. Finally, the percentages of each facility in the rest areas and the service areas of the tolled network of the country were computed.

In the study, tolled motorways with a length over $30 \mathrm{~km}$ were considered. Generally, shorter tolled motorways correspond to specific segments with a high construction cost, like a long (or important) tunnel or bridge or access to a city. Therefore, countries with no toll motorways longer than $30 \mathrm{~km}$ or a total network less than $100 \mathrm{~km}$ were not considered. Additionally, countries that require vehicles to show a vignette were not considered because of the flexibility it offers. With a vignette, all the roads can be used as desired with no additional cost to leave or enter the motorways at any moment or place. Consequently, the countries 
included in this study were Italy, Portugal France, Spain, Poland, Greece, and the Slovak Republic. However, in these countries, with a toll motorway network over $100 \mathrm{~km}$, segments that were longer than $15 \mathrm{~km}$ were also considered, because, typically, these special short stretches are connected to the main toll network, and they constitute a continuation of an itinerary or access to a port or to a major city. The names of the cities are written in the official language of the country, except for Greek names, which are written in English.

Two classification terms for areas were used in this evaluation-(1) service areas were considered independently and (2) the term "area" includes both rest and service areas because they both provide a safe place to park a vehicle in the case of emergency, outside the carriageway and not on the shoulders, despite the lack of some facilities.

With regard to the analyzed facilities, they include elements important to travelers: petrol station, toilets, restaurants, cafés, shops, picnic areas, playing areas for children, garages, and showers. Additionally, due to the importance of toll motorways for holiday trips in the EU, the analysis included the presence of hotels in service or rest areas, which can be reached without leaving the motorway; the areas for auto-caravans, because drivers can chose a route according to the availability of these places; and possible leisure activities in the areas, like museums, activities for children, and monumental heritage accessible walking, without exiting the infrastructure.

The research was conducted in April 2019 using information available on web pages of the companies that own or manage the toll motorways and checked by online resources such as Google Maps, Google Earth, and Google Street View. Distances were computed using the Kilometer Points (KPs) of the respective motorways.

\section{Results and discussion}

The following results include the countries of the European Union with a total toll network length greater than $100 \mathrm{~km}$. Additionally, this evaluation includes regulations about the maximum or minimum distances between rest or service areas in each country. Some thresholds for the distances are necessary to evaluate the network (Table 3). Values in the literature (Banerjee et al., 2009; Gates et al., 2013; Kolondinskaja and Bertuliene 2020; Pérez-Acebo \& Romo-Martín, 2019; Romo-Martín \& Pérez-Acebo, 2018; Seya et al., 2020) supported a threshold of $30 \mathrm{~km}$ for the average safe value between areas (service and rest areas). A larger value could be dangerous, because more than $15 \mathrm{~min}$ would be required, on average, to reach a safe stopping place. For the maximum distance between areas, $60 \mathrm{~km}$ was proposed as the limit, because it implies at least $30 \mathrm{~min}$ (at a speed of $120 \mathrm{~km} / \mathrm{h}$ ) to arrive to the next area. In the case of service areas, 50 and $80 \mathrm{~km}$ are suggested as reasonable thresholds for average distance and maximum distance between them, respectively. 
Table 3 Thresholds for average distances and maximum distances in areas and service areas

\begin{tabular}{lll}
\hline Values for & Service areas & Areas (rest and service) \\
\hline Average values & Safe: $\mathrm{D}<30 \mathrm{~km}$ & Safe: $\mathrm{D}<20 \mathrm{~km}$ \\
& Acceptable: $30 \mathrm{~km}<\mathrm{D}<50 \mathrm{~km}$ & Acceptable: $20 \mathrm{~km}<\mathrm{D}<30 \mathrm{~km}$ \\
& Dangerous: $\mathrm{D}>50 \mathrm{~km}$ & Dangerous: $\mathrm{D}>30 \mathrm{~km}$ \\
Maximum values & Safe: $\mathrm{D}<60 \mathrm{~km}$ & Safe: $\mathrm{D}<40 \mathrm{~km}$ \\
& Acceptable: $60 \mathrm{~km}<\mathrm{D}<80 \mathrm{~km}$ & Acceptable: $40 \mathrm{~km}<\mathrm{D}<60 \mathrm{~km}$ \\
& Dangerous: $\mathrm{D}>80 \mathrm{~km}$ & Dangerous: $\mathrm{D}>60 \mathrm{~km}$ \\
\hline
\end{tabular}

\section{Italy}

In Italy, the "Codice della Strada" (Ministero delle Infrastrutture e dei Transporti, 1992), its application regulation, "Regolamento di attuazione", (Gazzeta Uffiziale, 1992), and their successive updates, are the fundamental laws about roads. They include all the regulations about the rest and service areas and also define them. According to these regulations, service areas on freeways must have a petrol station and a garage, and are allowed to, but not required to provide a café or restaurant, a hotel, an emergency phone, toilets, places for washing cars, and trash bins. Rest areas must be equipped with a parking zone, a green area, a sidewalk, places to sit down, toilets and bins, and, if possible, with picnic areas. Moreover, in 2015, Ministry of Infrastructures and Transports published a rule focused on the restructuration of the service area network due to their low profitability, imposing a minimum distance of $50 \mathrm{~km}$ between service areas (Ministero delle Infrastrutture e dei Transporti, 2015).

Italy's tolled motorway network includes $5063.95 \mathrm{~km}$ of double carriageway, distributed across 22 motorways). There are no toll motorways with an average distance between service areas over $50 \mathrm{~km}$ (dangerous), but there are 10 cases with an average distance over $30 \mathrm{~km}$ (acceptable level). However, there are 2 segments with a maximum distance between service areas over $80 \mathrm{~km}$ (both directions of A-25 motorway) and 3 segments with a maximum distance over $60 \mathrm{~km}$ (both directions of A-3 and one direction of A-21). Both directions of A-14 have a segment with a distance between service areas of approximately $60 \mathrm{~km}$. With regard to areas, there are 5 cases with an average distance between areas over $30 \mathrm{~km}$ (A-3, A-25, and one direction of A-21). These motorways also have a maximum distance between areas of over $60 \mathrm{~km}$, implying that there is not any safe place to park for $30 \mathrm{~min}$.

The average values of average distances between areas, service areas, toilets, cafés, and shops is less than $30 \mathrm{~km}$, and is approximately $38 \mathrm{~km}$ for restaurants. These values and their ratios in the network are acceptable. However, the average values for picnic areas and playing areas for children are extremely high (over $140 \mathrm{~km}$ ) and the ratios in the network are greater than $220 \mathrm{~km}$ per area, with only 5 service areas out of $330(1.5 \%)$ and $45(13.6 \%)$ providing a picnic area and playing area, respectively. At rest areas, the percentage for picnic and playing areas is also very low, $20.5 \%$ and $1.4 \%$, respectively. The maximum distance without any kind 
of facility or area is the $81.6 \mathrm{~km}$-stretch in both directions of the A-25 (PescaraTorano). All the service areas have toilets, a shop, and a café, and $81.5 \%$ of them have a restaurant. Regarding other facilities, there are 2 service areas with leisure activities (a church), 23 garages, and 11 hotels in the network. 140 places for auto caravans are available at service areas (42.4\%), and 1 more at a rest area, which is adequate and the majority $(51.5 \%)$ of the service areas have showers available for travelers. Complete information about the Italian tolled motorway network is available in the Appendix A: Data from Italy (Table A.1, A.2 and Fig. A.1).

\section{Portugal}

In Portugal, the laws that establish the regulations about the protection of adjacent areas of the roads and the activities in those zones are included in the "Estatuto das Estradas da Rede Rodoviária Nacional", which was approved by the Law $\mathrm{n}^{\circ}$ 34/2015, of April 27 (Diário da Republica, 2015). This law classifies these areas into service and rest areas depending on the presence of a petrol station, as presented in the introduction. Additionally, there is another regulation, the "Portaria n, ${ }^{\circ}$ 54/2015 de 27 de fevereiro" (Ministérios da Economia e do Ambiente, Ordenamento do Território e Energia, 2015), which establishes the conditions to locate a service area and the facilities it may include. More specifically, it indicates that on toll motorways, service areas must be provided in both directions with the same facilities or the areas can be connected to provide access to the area for travelers in both directions. Service areas must have a petrol station, a parking area, toilets, emergency phones, a shop, a relaxation zone, and panels with tourist information. A restaurant and a place for children are optional in all service areas. On roads with an Annual Average Daily Traffic below 16,000 vehicles, the panel with touristic information, the shop, and the relaxation area are optional too. The regulations specify a minimum distance of $30 \mathrm{~km}$ between service areas, but do not specify a maximum distance. For rest areas, an area with shade, lighting, and drinking water are only recommended, without additional requirements or recommendations.

The toll motorway network in Portugal has a length of $2812 \mathrm{~km}$, comprising 32 motorways. Most of the values of average, maximum, and minimum distances for areas and service areas are identical because there are very few rest areas in the network. Only freeways A-1 and A-22 have different values due to the presence of rest areas ( 4 and 9 rest areas, respectively). Therefore, although none of the motorways has an average value between service areas greater than $50 \mathrm{~km}$, considering all kind of areas, as places for an emergency stop, average values over $30 \mathrm{~km}$ can be observed ( 25 cases). With regards to maximum distances between areas, some freeways have a distance over $60 \mathrm{~km}$, as in motorway A-13, with a stretch of $89 \mathrm{~km}$ without any area or facility, or on A-11 with $72.3 \mathrm{~km}$. Other examples near the acceptance level are A-6 $(57.3 \mathrm{~km})$ and A-23 $(51.7 \mathrm{~km})$. Values for service areas, areas, and the main facilities are similar in Portugal due to the few rest areas in the network and to the fact that the service areas are usually well equipped. A shop and toilets are available in all the service areas, but cafés and restaurants are not always present, but are common $(94.8 \%, 88.8 \%$ of the times, respectively). Picnic areas and 
playing areas for children are available in more than $73 \%$ of the service areas. There are 44 garages in the network (32.8\%), a considerably high value, and 11 hotels. However, rest areas are poorly equipped, where only 4 out of $13(30.8 \%)$ have toilets and a picnic area. (Complete information in Appendix B: Table B.1, B.2, Fig. B.1). The existing network does not suggest an explicit minimum length for the compulsory inclusion of a service area because of the inconsistent availability of areas on short roadways. For instance, the A-21 motorway $(21 \mathrm{~km})$ has a service area in each direction, and the A-14, with $40 \mathrm{~km}$, has no areas (Table B.3).

\section{France}

The document "Instruction sure les Conditions Techniques d'Aménagement des Autoroutes de Liaison" is the reference document for the design and management of the interurban freeways in France (Ministère de l'écologie, du développement durable et de l'énergie 2015). It classifies the rest and service areas depending on the presence of a petrol station, as commented in the introduction, using similar definitions. It establishes that for a new infrastructure, there must be a rest area every $30 \mathrm{~km}$, and a service area every $60 \mathrm{~km}$. On motorways with moderate or low traffic, or without tolls, services can be offered outside of the motorway right-of-way (not in the adjacent area or property, but with some distance from the main road). Apart from requiring a petrol station in service areas, no additional specifications are given about the facilities.

In 2019, there were more than $11,600 \mathrm{~km}$ of motorways, 8160 of them corresponding to 38 toll motorways (more than 70\%). There are no motorways with an average value between areas over $30 \mathrm{~km}$, and only 16 cases over $20 \mathrm{~km}$. Similarly, there is no stretch with a maximum distance between areas over $60 \mathrm{~km}$, and only 8 cases are over $40 \mathrm{~km}$. The A-7 and A-26 motorways have maximum distances over $50 \mathrm{~km}$. With respect to service areas, there are 11 stretches with an average distance over $50 \mathrm{~km}$, and 4 stretches with a maximum distance between service areas over $80 \mathrm{~km}$ : both directions of A-16 (82 and $87 \mathrm{~km})$ and A-26 (98 km in each direction). These high values must be avoided, since more than $40 \mathrm{~min}$ are needed to reach the next petrol station. In some cases, the minimum distance between service areas is over $40 \mathrm{~km}$ (6 cases).

Considering the whole toll network in France, values over $20 \mathrm{~km}$ can be found for the average value of the average distances and the ratios for areas, toilets, and picnic areas. The values for service areas are higher than in other countries, $37.55 \mathrm{~km}$ for the average value of average distance and $45.46 \mathrm{~km} /$ service area for the ratio (Complete information is available in Appendix C: Table C.1, C.2 and Fig. C.1). Unlike in Portugal, where the approach was to focus on the placement of service areas (134) instead of rest areas (13), in France, there is a longer distance between service areas (359), but a high quantity of intermediary rest areas in between (677 rest areas in the total network). This solution in France provides a safe place to park more frequently and it is said to reduce the collisions caused by drowsy driving (Jung et al., 2017).

The average values and ratios for areas and toilets are identical, since all service and rest areas are equipped with toilets. Values for services areas and shops (and 
petrol stations) are also identical, as all service areas have a shop. Similar values of averages and ratio are found for cafés as a café can be found at the $88.6 \%$ of the service areas and a restaurant at $66.3 \%$. A total of 7 cafés and 1 restaurant are placed in the rest areas. Picnic areas are also frequent in the network, 93.3\% of service areas and $78.7 \%$ of rest areas, with lower values in the case of playing areas for children. A wide variety of activities are present at the 29 places with leisure activities at service areas and 14 at rest areas, with a wide variety: recreation activities in summer, expositions, mini golf, petanque (a boules sport), a centre for flower interpretation, a castle, a lake, gardens, panoramas, Roman ruins, and museums. 100 places for auto caravans can be found, 40 hotels (39 in service areas and 1 in a rest area), only 4 garages and showers are available in $45.5 \%$ of the service areas and in $8 \%$ rest areas.

\section{Spain}

The main document about roads in Spain is the "Ley 37/2015, de 29 de septiembre, de Carreteras" (Boletín Oficial del Estado, 2015) which defines the rest and service areas, according to the definitions commented in the Introduction. It does not indicate the necessary facilities. Additionally, there is a previous document, a Ministry order, O.C. 320/1994-C y E, about service areas, from 1994 (Ministerio de Obras Públicas, Transportes y Medio Ambiente, 1994). It indicates that service areas will be placed in areas with a lack of facilities and it establishes that the minimum distances between service areas is $20 \mathrm{~km}$ in the same direction and the maximum distance is recommended to be between 40 and $60 \mathrm{~km}$, which longer distances requiring a justification. Additionally, for service areas, the following facilities are recommended: parking area, petrol station, café and relaxation area, and as complementary facilities, auto parts store, restaurant, shop, hotel, garage, information office, car wash area, playing area for children, and other to make the journey safer and more comfortable.

Spain has the longest motorway network in the EU, 15,523 km (EUROSTAT, 2019), but less than $2800 \mathrm{~km}$ were toll motorways as of April 2019. There are not any freeways with an average distance between service areas over $50 \mathrm{~km}$, but in 9 cases the average distance is over $30 \mathrm{~km}$. The maximum distance between service areas is not over $80 \mathrm{~km}$ in any case, but there are 2 motorways with both directions over $60 \mathrm{~km}$ : AP-7 (IV) and AP-15. These values are acceptable as all the values are below the acceptance levels. Regarding areas, the average distance between them is not over $50 \mathrm{~km}$ in any case, but in 3 motorways, the values are over $30 \mathrm{~km}$. Only the AP-7 motorway, in the stretch Cartagena-Vera, has a maximum distance over $60 \mathrm{~km}$. (Complete information is available in Appendix D: Table D.1, D.2, and Fig. D.1).

The average value and the ratio for areas are approximately $20 \mathrm{~km}$, which is adequate. Average values for the average distances between service areas, toilets, shops, and petrol stations are below $25 \mathrm{~km}$ but the ratios resulted in values over $30 \mathrm{~km}$ per facility, because there are two motorways with lengths below $30 \mathrm{~km}$ and without service areas (AP-51, AP-61). The values for shops are lower than for services areas, as there is a rest area with a shop. Nonetheless, the values for toilets are similar to 
those of service areas, because all the service areas have toilets but only $2.5 \%$ of the rest areas (3 out of 114) have this facility. In Spain, the same general approach applied in France is followed for long toll motorways: Service areas at regular intervals with rest areas between them. Hence, there are areas at an adequate interval, providing a frequent opportunity to stop in case of emergency, but almost none of the rest areas has toilets available. The average values of the maximum distances are approximately $40 \mathrm{~km}$ for service areas, toilets, petrol stations, and cafés.

With regard to the facilities in service areas, there is a café and a restaurant in $78.6 \%$ and $57.2 \%$ of them, respectively. Picnic areas and places for children are not as frequent, less than $30 \%$ of the areas include them. 12 hotels can be found in the network and 21 service areas have showers for motorists. There is no garage in the entire toll network. Leisure activities are available at 6 service areas and 2 rest areas, including recreation activities in summer, an ancient bridge, and Roman ruins. Conversely, rest areas are poorly equipped. Apart from the commented lack of toilets, only $63.6 \%$ of them have a picnic area and less than $30 \%$ have a space for children.

\section{Poland}

In Poland, the specifications for rest and service areas can be found in the regulation Dz.U.2016.0.124.t.j. (Ministerstwo Transportu i Gospodarki Morskiej, 2016), which specifies the minimum distances between areas depending on the road type. For motorways, there must be a minimum distance of $15 \mathrm{~km}$ between two consecutive areas (rest and service areas) and a minimum distance of $3 \mathrm{~km}$ from an area to the country border. For multilane highways, there must be a minimum distance of $10 \mathrm{~km}$ between two consecutive areas (rest and service areas) and a minimum distance of $1.5 \mathrm{~km}$ from an area to the country border. During the reconstruction or renovation of an existing road, the previously described distances can be reduced by $50 \%$ if areas are present. The regulations do not provide a maximum distance. Polish standards are focused on the minimum distance to maintain the competence between service areas, avoiding, for instance, the concentration of petrol stations in a specific area and allowing each service area to maintain its influence area.

The regulation also establishes the facilities that each type of area must provide, according to three types. Type I areas have a rest function and must be equipped with a parking space, rest and sanitary facilities, and lighting. Small catering facilities, such as cafés, are allowed too. Type II areas must have a rest and service function and must provide the facilities of Type I areas in addition to a petrol station, a restaurant, commercial facilities, and tourist information. Type III areas have a rest and service function, and in addition to the facilities of Type II areas, they must include accommodation facilities (hotels), and, depending on the needs, a post office, a bank, and an insurance office. According to the definitions in the Introduction, Type I areas can be classified as rest areas and Type II and III areas are catalogued as service area.

There are 3 tolled motorways in Poland; A-1, A-2 and A-4, comprising a total length of $861.9 \mathrm{~km}$. The average distance between areas is under $30 \mathrm{~km}$ on the three motorways, and on two of them, under $20 \mathrm{~km}$, which is optimum. However, on the 
A-2, there is a stretch of $49 \mathrm{~km}$ without any area, close to the dangerous limit. With regard to the service areas, the three motorways have average distance between them under $50 \mathrm{~km}$, so their values are near the acceptance threshold $(47.9 \mathrm{~km}$ in A-1 and $43.18 \mathrm{~km}$ in A-2). Moreover, there is a stretch of $80.3 \mathrm{~km}$ on A-2 without service areas, becoming an unsafe zone. In the A-1, there are maximum values of approximately $65 \mathrm{~km}$ in both directions (Complete information is in Appendix E: Table E.1, E.2, and Fig. E.1).

In Poland, there are also rest areas between service areas, implying that values and ratios of areas and service areas differ substantially: from 19.7 to 40.5 for the average values of the average distance and from 20.5 to $45.4 \mathrm{~km} /$ area for the ratios. The figures for toilets are identical to those for areas because all the service and rest areas in Poland are equipped with restrooms. Shops, cafés, and picnic areas are available in all the service areas and almost all of them have a restaurant $(89.5 \%)$ and playing areas for children (94.7\%). There are 10 hotels and 12 showers in the toll network. However, there is no garage, areas for auto caravans, and leisure activities. The majority of the rest areas in Poland have a picnic area $(84.8 \%)$ and playing areas for kids (67.4\%). There are 10 cafés, but no restaurants at rest areas.

\section{Greece}

There are $1739 \mathrm{~km}$ of motorways in the main toll network (motorways with a length over $15 \mathrm{~km}$ ). Branches of the A-6 (Eleusis-Athens Airport), A-62 and A-64, although paying is necessary to access them, are shorter than $15 \mathrm{~km}$, and therefore, were not considered in the analysis. Similarly, the bridge Charilaos Trikoupis (Rio-Antirio) and the undersea tunnel Aktio-Prevenza were not taken into consideration due to their short length. Moreover, there are some motorways with more than $15 \mathrm{~km}$; the A-25 (Thessaloniki-Serres_-Promachonas), the A-29 (SiatistaAlbania), and the stretch of the A-1 between Thessaloniki and Ezvonoi, which connect the A-2 (Egnatia Odos) with borders of other countries, but they have a unique toll barrier access system near the border (in Promachonas, Ieropigi, and Ezvonoi, respectively), and from the first exit after the toll barrier it is possible to exit and return to use the motorway without paying again. Consequently, these 3 motorways, although they are long (more than $70 \mathrm{~km}$ ), only have a paying stretch of less than $15 \mathrm{~km}$. Some of the freeways were divided in two parts. A-1 was divided because there is a stretch between the two parts that is not finished yet. For the A-2 and the A-6, the freeway segments around Thessaloniki and Corinth, respectively, are free, and therefore, it is possible to leave via any of the exits of this stretch, take advantage of the facilities in these cities and then return to the freeways without extra costs. No regulations about service and rest areas were found in Greek laws. For each toll motorway, the location and quantity of the rest and service areas is approved in advance in the project phase, but without following any general national standard.

The average distance between areas on most of the freeways is less than $12 \mathrm{~km}$, which is an optimum value. However, on the motorway A-2 (Egnatia Odos), average distances are extraordinary high, over the acceptance level of $30 \mathrm{~km}$. This motorway 
is quite different from the rest in the EU. It is the longest infrastructure in Greece, $670 \mathrm{~km}$ in total, from Igoumenitsa at the Adriatic Sea to Kipoi at the border with Turkey. It has 9 central toll barriers along the itinerary but the access and exits are not controlled. Nevertheless, it is very difficult to avoid these central toll barriers, because they are placed along segments where there are no alternative ways or the detour route would be more than double of the distance to reach next access using local roads. The rest and service areas that are analyzed in this effort are those that are adjacent to the motorway, which are also indicated on the website of the company that manages the infrastructure. There is a single service area, with a petrol station, along the $670 \mathrm{~km}$ route. However, because of the possibility to leave the motorway at an exit and return to the same point (without extra costs), the petrol stations located in the cities or villages near the motorway are advertised on the motorway too. Thus, motorists can reach petrol stations, and other facilities, but sometimes they must travel more than $2 \mathrm{~km}$ from the exit ramp. Habitual local drivers will likely know the facilities at each exit, but other drivers might be concerned about leaving the infrastructure to reach the facility they need. Moreover, when planning a journey, they must check the services in the cities, and not in the areas of the motorway itself. Consequently, the A-2 freeway can be considered as dangerous, not providing rest and service areas at an acceptable rate. Unlike the rest of the European countries, which control all the accesses to a toll motorway, the employment of central toll barrier for selected segments (those that are difficult to avoid) is a typical approach in Greece. The rest of the motorways also employ this strategy, but some accesses and exits are also controlled. However, in some places, it is possible to leave and come back to the same point for free as there is not any control in those locations. Thus, apart from the facilities in the areas of the motorway, drivers can access to those outside the motorway. However, non-habitual drivers may be reluctant to use this practice, as they do not know the facilities in each city and if it is necessary to pay again to return to the freeway. Consequently, only habitual drivers may fully take advantage of this option.

Excluding the A-2, the rest of the freeways have maximum distances between areas below $40 \mathrm{~km}$, which is below the safe threshold. For service areas, apart from the unique service area on the A-2, there are no average distances between service areas over $50 \mathrm{~km}$ and only 4 stretches over $30 \mathrm{~km}$. Similarly, there are 3 stretches with a maximum distance over $60 \mathrm{~km}$, but the A-2 freeway is the only one over $80 \mathrm{~km}$ (Complete information is available in Appendix F: Table F.1, F.2 and Fig. F.1).

Despite the encouraging values for areas and service areas, the facilities at the areas do not have similar positive values. Except from areas and toilets, service areas and the rest of the facilities have an average value of the average distance in the network over $60 \mathrm{~km}$ and their ratio is over $50 \mathrm{~km}$. The presence of the previously described two stretches of the A-2 distorts these values. Without the effect of the A-2, the average values of average distances for some facilities can be regarded as adequate: shop and petrol station $(25.5 \mathrm{~km}$, similar to service area), restaurant $(30.4 \mathrm{~km})$, and café $(27.4 \mathrm{~km})$, because there is a restaurant or a café in more than $80 \%$ of service areas. Nevertheless, for the rest of the facilities, the rest and service areas are poorly equipped in Greece. Playing areas for children are available in 5 
service areas (out of $68,7.4 \%$ ), with 4 of them in the A-8 and none at rest areas. Picnic areas are also scarce, 16 in the entire toll network, with 13 concentrated on the A-2. There are 10 garages and 3 hotels, but 2 of them are on the A-6, near the Airport of Athens. Fewer than 50\% of the rest areas are not equipped with toilets (48.2\%). Furthermore, a substantial quantity of rest areas only consist of an adjacent area to the main carriageway, separated from it by 3 or $4 \mathrm{~m}$ with only road markings and therefore, are not likely an ideal safe place to park and rest.

\section{Slovak Republic (Slovakia)}

There are only two tolled motorways in Slovakia (officially Slovak Republic), D-1 from Bratislava to Presov and D-2, from Kúty to Cunovo. However, D-1 was divided in 2 parts because there is a part in the middle that has not been completed. The total length of the toll motorway network is $411 \mathrm{~km}$. As shown, the average distance between areas is less than $20 \mathrm{~km}$ in 5 of the cases and only in one direction of the D-1 (II) is over $20 \mathrm{~km}$, which are safe values. However, in the second part of the D-I (Zilina-Presov) there is a stretch of $82 \mathrm{~km}$ without any area. Similarly, the average distance between service areas is around $30 \mathrm{~km}$, and only 2 cases are over $30 \mathrm{~km}$, which is adequate. Nevertheless, once again the second part of the D-1 (ZilinaPresov) has a stretch of $91 \mathrm{~km}$ without petrol station (Complete information is available in Appendix G: Table G.1, G.2 and Fig. G.1).

Analyzing the Slovak toll network globally, excluding the playing areas for children, the rest of the areas and facilities have an average value of the average distance below $30 \mathrm{~km}$. The unique facilities that can be found in Slovak service stations are petrol stations (as per definition), toilets, and shops. Nevertheless, except for toilets, their ratios are the highest $(34.3 \mathrm{~km} /$ facility or service area). The reason is that, although not more than the $65 \%$ of service areas have other facilities, the rest areas have a good percentage of other facilities: restaurants $(55.2 \%)$, cafés $(62.1 \%)$, picnic areas $(69.0 \%)$, and playing areas for kids (55.2\%). On the contrary, the maximum distance for all the area types and commented facilities in the network is over $80 \mathrm{~km}$. There are 3 hotels and 1 shower available in the network, but there are no garages and areas for auto caravans.

No specifications about rest and service areas were found in the Slovak regulations.

\section{Global analysis}

As shown in the country by country analysis, there is substantial variety in the distances between service and rest areas and facilities in each country. The specifications differ in their distance requirements (or lack thereof) and the facilities. The maximum distance between service and rest areas can be regarded as the most important feature from the road safety perspective. Nonetheless, as shown in Table 4, France is the unique European country with toll motorways that establishes a maximum distance, 60 and $30 \mathrm{~km}$ for service and rest areas, respectively. In Spain, the values are only recommended. Conversely, minimum distances are 


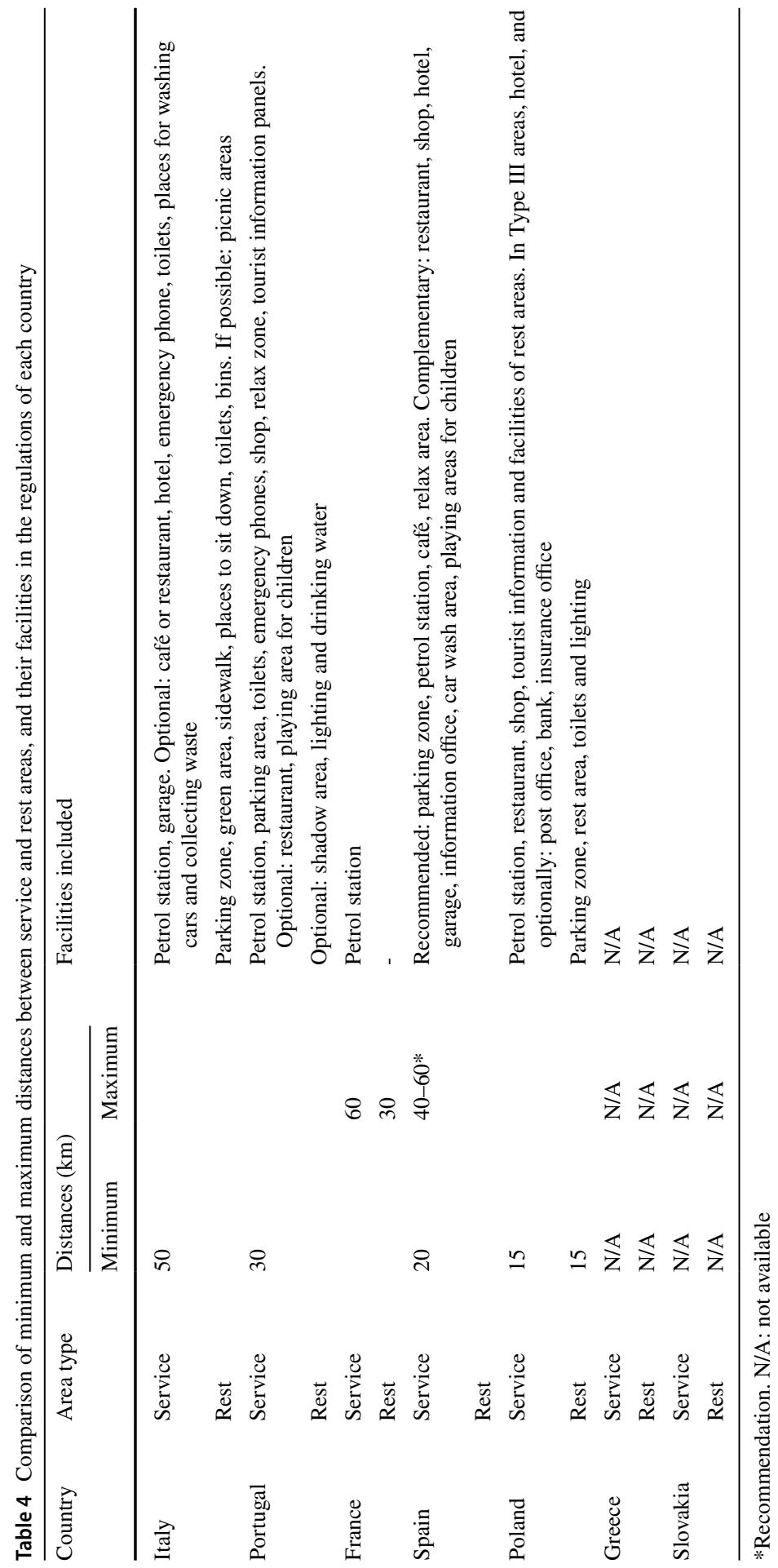


indicated in the regulations in more countries: Spain, Portugal, Italy, and Poland. As petrol is the primary commercial activity for highway transportation, minimum distances are imposed to guaranty the economical viability of the service areas. In the case of Italy, minimum distances are imposed by means of ministry order, which aims to eliminate the excessive amount of service areas due to their low profitability. Specifications about distances between rest areas are only included in Poland and France.

Regulations of the compulsory facilities in the countries are not as different as the distance guidance. In service areas, a petrol station is required, and, generally, toilets, shops, a place to eat something (café or restaurant), a parking zone, and information must be provided (or are generally provided). Other facilities described in this paper are optional. France and Poland are the only countries that establish facilities in rest areas as compulsory. However, these requirements are not currently fulfilled in all rest areas.

Table 5 compares the global values of the network in each country. The two approaches of using rest areas to complement the service areas result in divergent overall values between the countries. Whereas in France, service areas tend to be spaced at a longer distance between them and rest areas are mixed among them to provide a safe zone more frequently, in Portugal, there are few rest areas and all the facilities are only found in service areas. Consequently, the average value between areas of any kind is the highest in Portugal and the lowest in France (although in Slovakia the value is even lower, the global network length is not comparable). Similarly, the ratio for areas in Portugal is the highest $(38.26 \mathrm{~km} /$ service area) and is one of the lowest in France (15.75). Once again in Slovakia a lower value is obtained. Greece cannot be compared due to the uniqueness of its network. Service area values are converse to these findings, where France has a high value for the average values of the average distances between service areas and Portugal is lower. However, Poland has a higher value and Spain and Italy obtained lower values. As previously described, this value depends on the length of each individual freeway, so, if ratios are compared, the values for Portugal and France are similar, and countries like Spain and Italy, with a similar network length, obtain better ratios.

The maximum distances found in each network also have great variability, ranging from 49 to $114 \mathrm{~km}$ for both area types and $64-337 \mathrm{~km}$ for service areas. For toilet facilities, the countries that impose that rest areas must have this facility (Italy and Poland), France, and Slovakia obtain positive (low average distance) values. France has the highest values for cafés (except for Greece), due to the larger separation between service areas and that all locations do not have this facility.

As shown in Table 6, France has very good values for picnic areas, because it is provided at almost all the service areas $(93.3 \%)$ and rest areas $(78.7 \%)$. However, values for playing areas for children are not as good because less than half of both area types are equipped with them. Values in Italy and in Greece are extraordinarily high because of the sparse inclusion of picnic areas and playing areas for children.

All the countries have at least one hotel in the toll network, with variable quantity, and only the Slovak Republic does not provide showers for motorists. Formal leisure activities are only present in France and in Spain and areas for auto caravans are available exclusively in Italy, France, and Spain. 


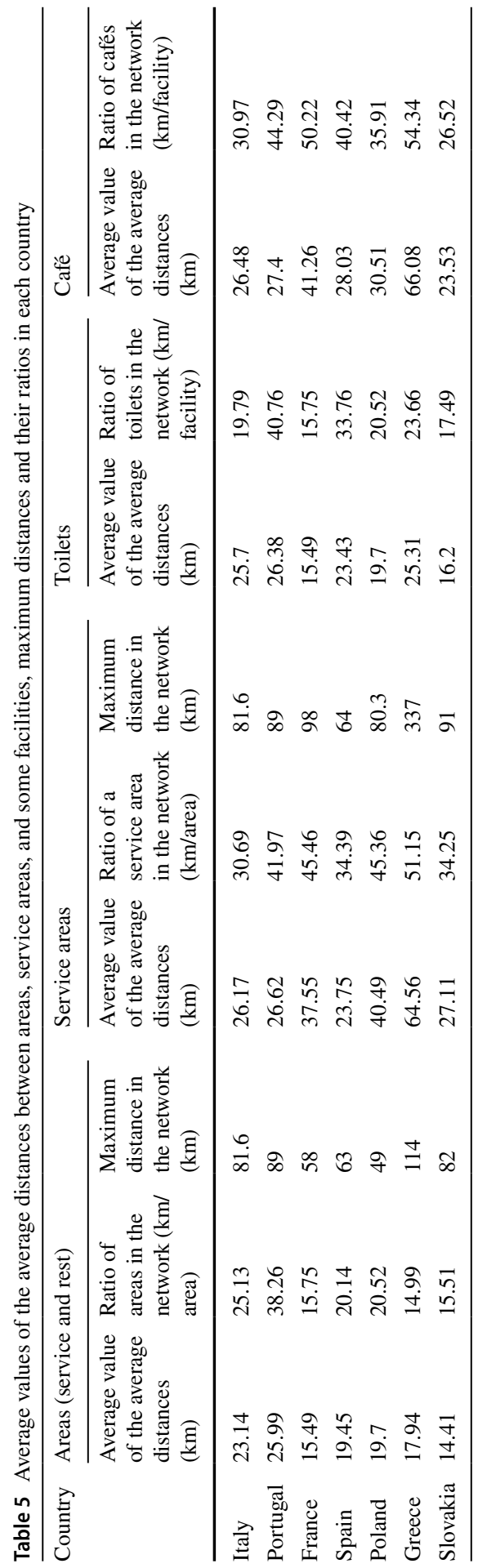




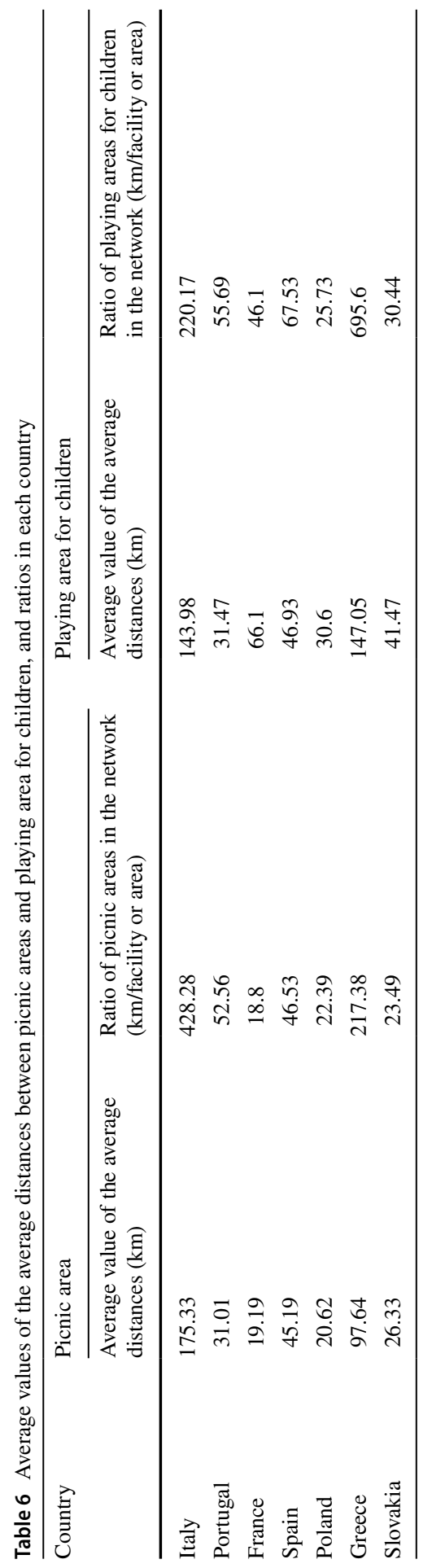


This evaluation shows that different policies exist in the countries of the European Union with tolled motorways regarding the distances between services and rest areas and their facilities. Considering that the borders of the countries within this community allow for relatively free movement and that passenger and freight traffic by road is the dominant mode of transport, common transport policies should be explored to standardize the distances between these types of areas. Tourists and truck drivers drive long distances, especially through the primary corridors in the EU, and would benefit from the establishment of a regular frequency for these safe places on toll motorways, which motorists do not usually abandon unless they have planned in advance. Standardized values for toll motorways could also be applied to free motorways. Although in this infrastructure, drivers can abandon it whenever and wherever they want without extra costs; they usually prefer to use the nearest adjacent areas and facilities. After a homogenization policy in the entire European Union, long distances without an area or a petrol station would be eliminated, and a consistent network of areas would be available at a reliable frequency. Hence, motorists would not be worried about what country they are crossing in the journey, since all of them would have a similar area distribution.

The facilities that must be provided in both types of areas should be considered for standardization also. It is adequate to have a rest area at a regular basis, but if they are not equipped with toilets, as in Spain, Italy, or Greece, they may not provide a satisfactory level of service to travelers. A minimum set of facilities for rest areas and for service areas should be defined for the whole EU-27. Thus, when drivers see a service or a rest area, they will know the minimum facilities that are available.

\section{Conclusions}

The spatial distribution of the rest and service areas in the toll motorway network of the European Union and their facilities were catalogued and analyzed to observe the difference between countries. Seven countries in the EU have a toll a motorway network over 100 km: Italy, Portugal, France, Spain, Poland, Greece, and Slovak Republic. The regulatory specifications of each country, when available, were also studied and summarized. While the maximum distance between service and rest areas is only established in France and suggested in Spain; the minimum distance is defined in Italy, Portugal, Poland, and Spain.

The average distance between area types and facilities and the ratios of the network in each country may be due to the different distribution policies applied in those countries, such as the French approach of alternating areas by placing service areas at longer distances and rest areas more frequently or the Portuguese approach of providing more frequent service areas (which have more services) without rest areas between them. Although these approaches may be intentional or unintentional, many of the other countries generally follow one of these two primary approaches. However, Greece differs from these approaches by allowing drivers to exit and return to the same point without extra costs in some locations. The Greek approach alleviates the need for providing as many service and rest areas because drivers can use facilities outside the motorway. These varying approaches lead to different 
potential deficiencies in each network. The facilities available at each area type also contain a wide variety of possibilities. Key observations from each country are provided below:

- Italy: The average distance between areas and service areas in all tolled motorways is adequate but there are some maximum distances that exceed the recommended acceptable limits. The rest areas are poorly equipped, less than $11 \%$ have toilets. Picnic areas and playing places for kids are almost non-existent in the Italian toll network.

- Portugal: The toll roadway network has a small quantity of rest areas (13) and facilities are available at service areas, which are distributed at appropriate intervals. This policy provides facilities at an adequate rate, but places for emergency stops are less frequent. In general, the service areas are properly equipped, but the rest areas are not adequately equipped.

- France: Service areas are located at longer distances, but rest areas are placed in between them. Hence, a safe place is more frequently provided with this mixed pattern of area types. Moreover, toilets are available in all the rest and service areas and many leisure activities can be found at the areas.

- Spain: Rest areas are provided regularly between service areas with reasonable maximum distances. However, the rest areas are poorly equipped with toilets provided at only 3 out of 114 .

- Poland: Following the same approach as France, rest areas are placed as intermediate areas between quite well-equipped service areas. The areas and their facilities are well-placed and provide many options to travelers. Toilets are available at both area types.

- Greece: The country has a unique approach relative to the other EU countries that allows drivers to exit at intermediate junctions to access local facilities without avoiding the tolled portion. Therefore, rest areas typically only provide a parking area.

- Slovak Republic: The average values for distances between areas and service areas and for ratios are adequate, despite some high maximum distances. The rest areas are extraordinarily well-equipped, providing cafés and restaurants at the majority of areas.

This heterogeneity in spatial distribution and facility availability suggests that benefits may accrue with the implementation of a common homogenization policy about rest and service areas, especially for toll motorways, which could also be applied to free motorways. A spatial evaluation of commercial services along free motorways, such as, petrol stations, restaurants, and lodging, could identify key locations that would benefit from areas installed by the respective road agency. This is of high interest in a commercial area like the European Union, where international trade and cross-border travel is robust with minimal impacts from crossing country borders. The standards for area frequency and equipment should be considered for application along the primary highway network, tolled or not. Specifically, the TEN-T corridors which facilitate a large portion of the passenger and freight traffic in Europe, would benefit from a reliable and expected network of areas. Therefore, 
the main conclusion is that a common policy in the European Union should be considered that would standardize the distances between service and rest areas and the provision of facilities in the road network. In particular, for the main highways in the European Union, homogenizing the criteria would provide safer road networks as long distances without areas or some facilities would be eliminated and a consistent expectation for travelers would be fulfilled.

Supplementary Information The online version contains supplementary material available at https://doi. org/10.1007/s12061-021-09421-3.

Author contributions HP-A: Conceptualization, Methodology, Software, Validation, Formal Analysis, Resources, Data curation, Writing_-Original Draft, Writing-Review \& Editing, Visualization, Supervision, Project administration, Funding acquisition. AR-M: Software, Validation, Formal Analysis, Investigation, Resources, Data Curation. DJF: Validation, Formal Analysis, Writing-Review \& Editing, Visualization, Funding acquisition.

Funding This work was supported by Erasmus + KA107 - 2017 project for mobilities from UPV/ EHU (Spain) to universities in United States, Morocco, Russian Federation and Kazakhstan; and Erasmus + KA107 - 2015 project for mobility from universities in the USA, Canada, South Korea and Russia to the UPV/EHU (Spain). Open Access funding provided thanks to the CRUE-CSIC agreement with Springer Nature.

\section{Declarations}

\section{Conflict of interest None.}

Availability of data and material Data can be provided after request.

Open Access This article is licensed under a Creative Commons Attribution 4.0 International License, which permits use, sharing, adaptation, distribution and reproduction in any medium or format, as long as you give appropriate credit to the original author(s) and the source, provide a link to the Creative Commons licence, and indicate if changes were made. The images or other third party material in this article are included in the article's Creative Commons licence, unless indicated otherwise in a credit line to the material. If material is not included in the article's Creative Commons licence and your intended use is not permitted by statutory regulation or exceeds the permitted use, you will need to obtain permission directly from the copyright holder. To view a copy of this licence, visit http://creativecommons.org/licen ses/by/4.0/.

\section{References}

Banerjee, I., Ho Lee, J., Jank, K., Pande, S., \& Ragland, D. R. (2009). Rest Areas: Reducing Accidents Involving Driver Fatigue. UC Berkeley Traffic Safety Center.

Boletín Oficial del Estado. (2015). Ley 37/2015, de 29 de septiembre, de carreteras. [Law 37/2015, of September 29, about roads]. Madrid: Bolentín Oficial del Estado.

Commission of the European Communities. (2001). White Paper: European Transport Policy for 2010: Time to Decide. Office for official publications of the European Communities.

Diário da República. (2015). Lei n. ${ }^{\circ} 34 / 2015$ de 27 de abril, aprova o novo Estatuto das Estradas da Rede Rodoviária Nacional. $1 .^{a}$ serie - N. ${ }^{\circ}$ 81, 27 de abril de 2015 [Law 34/2015, of April 27, which approves the new Road Code of the national road network]. Lisbon: Diário de República.

Eksler, V. (2008). Exploring spatial structure behind the road mortality of regions in Europe. Applied Spatial Analysis and Policy. https://doi.org/10.1007/s12061-008-9008-2 
European Communities. (2005). Trans-European Transport Network TEN-T Priority Axes and Projects 2005. Office for Official Publications of the European Communities.

European Parliament and Council. (1996). Decision No 1692/96/EC of the European Parliament and of the council of 23 July 1996 on Community guidelines for the development of the trans-European transport network, No L 228/1, p. 1-104. Official Journal of the European Communities.

European Parliament and Council. (2004). Decision No 884/2004/ED of the European Parliament and of the council of 29 April 2004 amending Decision No 1692/96/EC on Community guidelines for the development of the trans-European transport network, L 167, 1-55. Official Journal of the European Communities.

EUROSTAT. (2019). Energy, Transport and Environment Statistics-2019. Publications Office of the European Union.

Findley, D. J., Schroeder, B., Cunningham, C., \& Brown, T. (2015). Highway Engineering. Planning, Design, and Operations. Waltham, MA: Butterworth-Heinemann.

Gates, T. J., Savolainen, P. T., Datta, T. K., \& Todd, R. G. (2013). Economic assessment of public rest areas and traveler information centers on limited-access freeways. Transportation Research Record. https://doi.org/10.3141/2346-08

Gazzeta Uffiziale. (1992). Decreto del Presidente della Repubblica 16 dicembre 1992, n. 495. Regolamento di esecuzione e di attuazione del nuovo codice della strada [Decree of the President of the Republic on December 16, 1992. Regulations for the execution and implementation of the new Highway Code]. Roma: Gazzeta Uffiziale.

González-Luque, J. C., \& Álvarez-González, F. J. (2002). La fatiga: ¿cada cuánto hay que descansar. [The fatigue: how often should we rest?], Salud Vial, 152, 32.

Jung, S., Joo, S., \& Oh, C. (2017). Evaluating the effects of supplemental rest areas on freeways crashes caused by drowsy driving. Accident Analysis and Prevention. https://doi.org/10.1016/j.aap.2016.12. 021

Kang, M. W., Momtaz, S. U., \& Barnett, T. E. (2015). Crash analysis and public survey for drowsydriving advisory systems. Journal of Transportation Engineering. https://doi.org/10.1061/(ASCE) TE.1943-5436.0000777

Kolodinskaja, J., \& Bertuliene, L. (2020). Layout of rest areas and their infrastructure development in the south-eastern region of Lithuania. The Baltic Journal of Road and Bridge Engineering, 15, 130145. https://doi.org/10.72507/bjrbe.2020-15.488

Kraemer, C., Pardillo, J. M., Rocci, S., Romana, M.G., Sánchez Blanco, V., \& del Val, M.A. (2009). Ingeniería de Carreteras. Volumen I. [Highway engineering. Volume I]. Madrid: McGraw Hill.

McArthur, A., Kay, J., Savolainen, P. T., \& Gates, T. J. (2013). Effects of public rest areas on fatiguerelated crashes. Transportation Research Record. https://doi.org/10.3141/2386-03

Ministère de l'écologie, du développement durable et de l'énergie. (2015). Instruction du Gouvernement du 13 Juillet 2015 portant sur les conditions techniques d'aménagement des autoroutes de liaison [Governent Instruction on July 13, 2015 on the technical conditions for the development of the connecting freeways]. Sourdun, France: Direction technique infrastructures de transport et matériaux.

Ministerio de Obras Públicas, Transportes y Medio Ambiente. (1994). Orden Circular 320/94 - C. y E. Áreas de servicio [Order 320/94 - C. and E. Service areas]. Madrid: Dirección General de Carreteras.

Ministérios da Economia e do Ambiente, Ordenamento do Território e energia. (2015). Portaria n. $^{o}$ 54/2015 de 27 de fevereiro [Ordinance no. 54/2015 of February 27]. Lisboa: Diário da República.

Ministero delle Infrastrutture e dei Transporti. (1992). Nuovo Codice della Strada. Decreto Legislativo N. 285 del 30 aprile 1992 [New code of the road. Legislative Decree No 285 of April 30, 1992]. Rome: Gazzetta ufficiale.

Ministero delle Infrastrutture e dei Transporti. (2015). Decreto Interministeriale relativo al Piano di ristrutturazione della rete delle aree di servizio [Interministerial decree on the restructuring plan of the network of service areas]. Ministero delle Infrastrutture e dei Transporti.

Ministerstwo Transportu i Gospodarki Morskiej. (2016). Dz.U.2016.0.124 t.j. Rozporzadzenie Ministra Transportu i Gospodarki Morskiej z dnia 2 marca 2016 r. w sprawie warunków technicznych, jakim powinny odpowiadać drogi publiczne $i$ ich usytuowanie [Journal of Laws 2016.0.124. Regulation of the Minister of Transport and Maritime Economy of March 2, 2016, on the technical conditions to be met by public roads and their location]. Warsaw: Ministerstwo Transportu i Gospodarki Morskiej. 
Pérez-Acebo, H., \& Romo-Martín, A. (2019). Service and rest areas in toll motorways in Poland: Study of distribution and facilities. Transport Problems, 14, 155-164. https://doi.org/10.20858/tp.2019. 14.2.14

Pérez-Acebo, H., Gonzalo-Orden, H., Findley, D. J., \& Rojí, E. (2020). A skid resistance prediction model for an entire road network. Construction and Building Materials. https://doi.org/10.1016/j. conbuildmat.2020.120041

Pérez-Acebo, H., Gonzalo-Orden, H., Findley, D. J., \& Rojí, E. (2021). Modeling the international roughness index performance on semi-rigid pavements in single carriageway roads. Construction and Building Materials. https://doi.org/10.1016/j.conbuildmat.2020.121665

Romo-Martín, A., \& Pérez-Acebo, H. (2018). Analysis of the location of service and rest areas and their facilities in Spanish paying motorways. Transportation Research Procedia. https://doi.org/10. 1016/j.trpro.2018.10.069

Santos, J., Ferreira, A., \& Flintsch, G. (2019). An adaptive hybrid genetic algorithm for pavement management. International Journal of Pavement Engineering. https://doi.org/10.1080/10298436.2017. 1293260

Seya, H., Zhang, J., Chikaraishi, M., \& Jiang, Y. (2020). Decisions on truck parking place and time on expressways: An analysis using digital tachograph data. Transportation. https://doi.org/10.1007/ s11116-018-9899-y

Taylor, W., Sung, N., Kolody, K., \& Jawad, A. (1999). Study of Highway Rest Area Characteristics and Fatigue Related Truck Crashes. Michigan State University.

Publisher's Note Springer Nature remains neutral with regard to jurisdictional claims in published maps and institutional affiliations.

\section{Authors and Affiliations}

\section{Heriberto Pérez-Acebo ${ }^{1}$ D $\cdot$ Ander Romo-Martín $^{2}$ (D) . Daniel J. Findley ${ }^{3}$ D}

Ander Romo-Martín

aromo004@ikasle.ehu.eus

Daniel J. Findley

Daniel_Findley@ncsu.edu

1 Mechanical Engineering Department, University of the Basque Country UPV/EHU, $\mathrm{P}^{\mathrm{o}}$ Rafael Moreno Pitxitxi, 2, 48013 Bilbao, Spain

2 Faculty of Engineering Bilbao, University of the Basque Country UPV/EHU, $\mathrm{P}^{\mathrm{o}}$ Rafael Moreno Pitxitxi, 2, 48013 Bilbao, Spain

3 Institute for Transportation and Research Education, North Carolina State University, Centennial Campus, Box 8601, Raleigh, NC 27695-8601, USA 